\title{
Child Marriage among Maasai Girl Students in Tanzania: The Case of Kilosa District
}

\author{
Jonathan Ndaula
}

\begin{abstract}
This study explored the reasons for persistence of child marriage among Maasai girl-students in Tanzania. Three research questions guided this study, namely: Why does girl students' marriage among the Maasai community of Tanzania continue to exist? What is the position of education stakeholders in protecting girls from child marriage? What strategies should be taken to address child marriage in the Maasai community? The study employed qualitative research approach where a case study design was used to explore the problem. It adopted interviews, focus group discussion and observations as research methods. Purposive and snowball sampling strategies were employed to get 39 participants who were involved in this study. Data were analysed qualitatively through thematic analysis strategies. The findings revealed that child marriage is still practiced in the Maasai community where the legible age for marriage of Maasai girls range from 6 to 15 years depending on the number of competing men and the economic status of the family of the boy or girl. Society members employ persuasion and pressure, transfer of students, pregnancy and corruption to enable marriage of Maasai girl students. In addition, the findings revealed that Maasai traditions and customs, fear of early pregnancies, corruption and irresponsibility of leaders, poverty and undervaluing of education are the factors contributing to persistence of child marriage among the Maasai girl students. The study recommends that the government in collaboration with other stakeholders should aggressively implement laws protecting children. A close monitoring of local leaders' actions by top government leaders to help combating child marriage is also recommended. Moreover, joint efforts are needed to educate society members and girl-students on the negative impact of child marriage and the importance of girls' education.
\end{abstract}

\section{Paper History}

Received: 15 May 2018

Accepted: 28 December 2018

\section{Key Words}

Child marriage; Maasai Girl Students; girl child's education; Tanzania

\section{How to cite this paper:}

Ndaula, J. 2018. Child Marriage among Maasai Girl Students in Tanzania: The Case of Kilosa District. Mkwawa Journal of Education and Development, 2(1): 49-71. DOI: https://doi.org/10.37759/mjed.2018.2.1.4

Contact: Jonathan Ndaula, P.O. Box. $65, \quad$ Kimamba, Morogoro, Tanzania. E-mail: ndaulajonathan@gmail.com 
Mkwawa Journal of Education and Development, Vol. 2, 49-71. DOI:

https://doi.org/10.37759/mjed.2018.2.1.4

\section{1.o Introduction}

Child Marriage among Maasai Girl Students in Tanzania

\subsection{Background to the problem}

Girls' access to education has increasingly become a global concern (Bali \& Mbavai, 2015). This is due to the understanding that education is the only tool for realising individual, national and global development. Ban Ki-Moon, the then United Nations Secretary General, once acknowledged that wise investments in education can transform individuals' life, national economies and our world (United Nations Educational, Scientific and Cultural Organization (UNESCO), 2014). Child marriage is a major challenge that limits girls from progressing in education. It is increasingly becoming a global challenge to the girls' access to education and consequently undermining global development efforts.

More than 700 million women alive today in the world were married before they reached the age of 18 years, 250 million of whom were in sex relation before their $15^{\text {th }}$ birthday (United Nations Children's Fund (UNICEF), 2013). If the current state of child marriage holds, 14.2 million girls will be married annually, equivalent to 39,000 girls daily, bringing a total of 140 million girls by $2020^{1}$ (World Health Organisation (WHO), 2013). In developing countries, the situation is worse compared to the developed countries. Statistics show that 1 in every 3 girls in developing countries is married by the age of 18 , and 1 in every 7 is married before reaching the age of 15 years (Harvey \& Myers, 2011).

In 2000, 164 governments agreed on the Dakar Framework for Action, EFA at the World Education Forum in Dakar, Senegal (UNESCO, 2015). Reaching the marginalised groups such as children with special needs, from disadvantaged ethnic minorities, remote and isolated communities was among the strategies to achieve the Dakar Framework. With goal 5, gender parity and equality, the framework focused on ensuring girls' full and equal access to basic education by 2015 (UNESCO, 2015). The post-2015 Sustainable Development Goals by the United Nations, goal 4 and 5 (Osborn, Cutter, \& Ullah, 2015) emphasise on girl's education to attain gender equality and equity for sustainable development by 2030 .

In Tanzania, child marriage prevalence rate is $37 \%$ (United Republic of Tanzania (URT), 2017). The prevalence of child marriage is more critical in regions dominated by pastoral societies as well as coastal areas dominated by Islamic culture (Backlund

${ }^{1}$ Of 140 million girls who will marry before 18,50 million will be under the age of 15 . 
Mkwawa Journal of Education and Development, Vol. 2, 49-71. DOI:

https://doi.org/10.37759/mjed.2018.2.1.4

Child Marriage among Maasai Girl Students in Tanzania \& Blomqvist, 2014). Pastoral societies, notably the Maasai, do not consider girls' education important where male parents see education to their daughters as wastage of resources (Bali \& Mbavai, 2015). Though the Tanzanian government mentions early marriage as an obstacle in its Education and Training Policy of 2014, it does not state the appropriate strategies to deal with the problem. The statutory laws also contradict the age of a child and legal age for marriage. In the Law of the Child Act number 21 of 2009, the government states in section 4 (1) that "a person below the age of 18 years shall be known as a child" (URT, 2009, p. 665). The marriage Act of 1971 permits marriage of a child aged 15 years on the consent of parents. These contradicting laws have to be amended if the government realizes that child marriage is a problem. The state has the role of making sure that every citizen has equal and enjoyable access to education (Beiter, 2006).

\subsection{Statement of the problem}

Girls' access to education has always been a big challenge in Tanzania and it is very evident among the Maasai tribe (Temba, Warioba \& Msabila, 2013). As various studies (Bachar, 2012; Carr-Hill \& Peart, 2005; Mtengeti et al., 2008; Mtewele, 2012; UNICEF, 2013; UNICEF, 2015; URT, 2017) indicate, child marriage is a major obstacle limiting girls from accessing and succeeding through educational opportunities among the Maasai and elsewhere. The Tanzanian government acknowledges that child marriage and pregnancies are the major cause for girls' high dropout rates in primary and secondary schools (URT, 1995, p. 19; URT, 2014, p. 41). Despite the measures taken by the government, civil society organisations and international community, child marriage is still prevalent in Tanzania where $36 \%$ of women aged 20-24 by 2016 were married before their $18^{\text {th }}$ birth date (URT, 2017). This calls for the need to critically study child marriage in order to determine the factors for its persistence amidst efforts to address it. This paper contributes to this by drawing on insights from Kilosa district in Morogoro region, Tanzania.

\subsection{Research objectives}

This paper addressed the following key objectives:

i. To explore the reasons for persistence of girl-students marriage among the Maasai society in Tanzania.

ii. To assess the role and position of education stakeholders in protecting girlstudents from marriage. 
Mkwawa Journal of Education and Development, Vol. 2, 49-71. DOI:

https://doi.org/10.37759/mjed.2018.2.1.4

Child Marriage among Maasai Girl Students in Tanzania

iii. To identify strategies relevant for combating girl-students' marriage in the Maasai community.

\subsection{Research questions}

This paper was guided by the following research questions:

i. Why does girl-students' marriage continue to exist among the Maasai community in Tanzania?

ii. What is the role of education stakeholders in protecting girl-students from child marriage?

iii. What strategies should be taken to assist in combating girl-students' marriage in the Maasai community?

\section{2. o Literature review}

\subsection{Human right theory - a theoretical perspective}

This study was highly informed by human rights theory when discussing child marriage and girls' education. In the study, education was viewed as a basic and fundamental human right for every person. This is due to the idea that education is the source of knowledge and contributes to the development of human personality (Beiter, 2006). In this paper, child marriage was considered as a violation of human right which then undermines other girls' rights. The United Nations recognises education as a human right in Article 26 of the Universal Declaration of Human Rights of 1948 (Donnelly, 2013). Since then 'right to education' is sounding everywhere in the UNESCO documents and international laws (UNICEF, 2007).

In addition, the right to education is provided in Article 13 of the International Covenant on Economic, Social and Cultural Rights of 1966 (Beiter, 2006). The goal of this human right-based approach to education is "to assure every child gets quality education that respects and promotes her or his right to diginity and optimum development" (UNICEF, 2007, p.1). UNICEF (2007) gives three dimensions of human right-based approach to education: right to access education, right to quality education and right to respect within education system. These three dimensions should be considered when developing strategies to improve girls' education. This paper is of the view that girls have the right to access education, right to quality education and right to be respected in the education system. 
Mkwawa Journal of Education and Development, Vol. 2, 49-71. DOI:

https://doi.org/10.37759/mjed.2018.2.1.4

Child Marriage among Maasai Girl Students in Tanzania The respect of girls in Tanzanian education system should entail all policies and curriculum implementation strategies that protect their rights. All impedments to girls' education need close attention to reduce their impact. Child marriage, in particular, should be adressed seriously by all education stakeholders to permit girls' success in education system.

\subsection{International perspectives on child marriage and girls' right to education}

Since the end of the Second World War much has been documented about women's rights and oppression. After the end of the Second World War, human rights began to be taken as a normal part of life and currently it has become a standard topic of international relations (Donnelly, 2013). This went parallel with efforts to invest in education, women education in particular, catalysed by the development of human capital theory (Williams, 2015). The United Nations, formed in 1945, in the preamble of UN Charter listed one of its four principle objectives as to reaffirm faith in fundamental human rights, in the dignity and worth of the human person, in the equal rights of men and women and (Donnelly, 2013). In 1948, UN adopted the Universal Declaration of Human Rights which aimed at protecting rights for all (Bingham, 2011). Article 26 of this declaration articulates rights to education (Donnelly, 2013) where education was for the first time recognized as a human right. Child marriage is recognized by international community as a major obstacle to girls' access to education (UNICEF, 2013). The United Nations in its post 2015 Sustainable Development Goals, Goal 4 and 5 (Osborn, Cutter, \& Ullah, 2015) emphasises on education to attain gender equality and equity for global sustainable development by 2030.

\subsection{Empirical review}

Various studies have been carried out in different parts of the world on child marriage among girls where they indicate the prevalence of the practice in the world. This has been activated by increased concern on girls and women's rights. A study by UNICEF (2001) indicates that child marriage is more common in sub-Saharan Africa and South Asian regions of the world. It further specifies that marriage at or shortly after puberty is also common in North Africa, Middle East and other Asian countries in societies with traditional lifestyles. About $40 \%$ of girls in middle-income countries are married young (Nguyen \& Wodon, 2012). 
Mkwawa Journal of Education and Development, Vol. 2, 49-71. DOI:

https://doi.org/10.37759/mjed.2018.2.1.4

Child Marriage among Maasai Girl Students in Tanzania In Tanzania, several studies on child marriage and girls' education (Bali \& Mbavai, 2015; Raymond, 2012; URT, 2017) have been carried out. A study by Bali and Mbavai (2015) explore the perception of the Maasai, Wa-Meru and Wa-Arusha agropastoralists on girls' education. It argues that their perception on girls' education is changing slowly. It recommends for community mobilisation and enacting laws against discrimination of girls. Mlekwa (1996) recommends alternative educational strategies to pastoral communities which will not affect their freedom, economy and social control. A qualitative study by Mtewele (2012) about the influence of traditional customs and practices on girls' education suggests that traditional customs and practices are negatively influencing girls' education in Morogoro region. A study by Michael (2014) explains the ambiguity created by the Marriage Act of 1971 concerning child marriage. The study explains that the act permits child marriage in one way or another when it allows marriage of girls at 15 years with parents' consent. The same government in the Law of the Child Act, 2009 (Section 4) defines a child as a person below the age of 18 years (URT, 2009). These contradictions are also stated in the study by URT (2017) where it recommends for reformation and harmonisation of these contradicting laws.

\subsection{Research gap}

In reviewing the literature, it was revealed that there is little information on child marriage among Maasai girl-students. Despite the fact that researchers and writers are aware that child marriage is the problem to girl students, they do not uncover the way child marriage is practiced by community members in the local contexts. The techniques employed by community members to marry girl-students and contextspecific reasons for persistence of child marriage practices are also not well addressed. This gap in literature necessitated the carrying out of a more specific research with conceptual framework that apply specifically to the study area, as recommended by UNICEF (2015) and URT (2017), since child marriage practice is context specific. The drivers and ways of practicing child marriage may vary between regions depending on varied culture.

\section{3.o Methodology}

This study employed a qualitative research approach. The approach allowed a researcher to study and understand child marriage as practiced by the Maasai in their community (Ary et al., 2010). With qualitative research approach, a researcher was able to explore the views of participants on the persistence of child marriage 
Mkwawa Journal of Education and Development, Vol. 2, 49-71. DOI:

https://doi.org/10.37759/mjed.2018.2.1.4

Child Marriage among Maasai Girl Students in Tanzania practices in the Maasai community, particularly secondary school girl students. The research design used was case study design where Kilosa district of Morogoro region was selected as a case study. A study by URT (2017) on drivers and consequences of child marriage in Tanzania recommends for studies in other regions not covered including Morogoro. The knowledge gap in literature rose the researcher's curiosity to carry out a more specific research in a specific setting as recommended by UNICEF (2015) and URT (2017) since child marriage practice is context specific. With this regard, Magabe ward was sampled to be the study area where the study was done at Magabe secondary school and the surrounding villages such as Village A, Village $\mathrm{B}$ and Village $\mathrm{C}^{2}$. This ward is highly inhabited by the Maasai ethnic group where it was easy to get the targeted population. Magabe secondary school is the only secondary school special for enrolling pastoral community students in Morogoro. The school is said to have high rate of girls' dropout (45.9\%) which is mainly caused by child marriage (See Table 2). The selection of this specific area enabled the researcher to study the problem from the Maasai context, thus getting relevant information. The targeted population was Maasai girls in schools, Maasai parents, teachers and low-level government leaders. From this population, of 274, a total number of 39 participants with categories described in Table 1 were sampled.

Purposive and snowball qualitative sampling strategies were used to obtain research participants. This was done purposely to get Maasai girl-students and their teachers who were well informed of students' marriage. The researcher decided to use purposive sampling because he intended to get participants who could best add to the understanding of child marriage practices in the Maasai community, and not the representatives of Maasai population.

Data collection instruments included interview, Focus Group Discussion (FGD) and documentary review. Thematic analysis strategy was adopted to assist in identifying major concepts or themes relevant to research questions and objectives (Kombo \& Tromp, 2006) during data analysis. The process of data analysis began in the initial stage of data collection process. A researcher began analysing and interpreting data immediately after the first interview. After data collection process final analysis and interpretation of the data were done inductively starting with a large set of data (interview transcripts and field notes) narrowing into smaller and important groups

2 These are pseudo names 
Mkwawa Journal of Education and Development, Vol. 2, 49-71. DOI:

https://doi.org/10.37759/mjed.2018.2.1.4

Child Marriage among Maasai Girl Students in Tanzania of key data (Airasian et al., 2012). The paper was then written where the data were presented and discussed accordingly.

Table 1: Participants' Demographics

\begin{tabular}{lcccccc}
\hline Cluster & Students & Teachers & $\begin{array}{c}\text { School } \\
\text { Board }\end{array}$ & $\begin{array}{c}\text { Government } \\
\text { Leaders }\end{array}$ & Parents & Total \\
\hline Males & o & 3 & 3 & 3 & 0 & 9 \\
Females & 23 & 2 & o & o & 5 & 30 \\
Total & $\mathbf{2 3}$ & $\mathbf{5}$ & $\mathbf{3}$ & $\mathbf{3}$ & $\mathbf{5}$ & $\mathbf{3 9}$ \\
\hline
\end{tabular}

\section{4.o Results and discussion}

This study explores the reasons for persistence of child marriage among Maasai girl students in Tanzania. It comprised of 39 participants from Maasai inhabited area of Kilosa district. The results of the study are presented as per the order of the research questions.

\subsection{Reasons for persistence of child marriage among the Maasai community}

The first research question was to explore the reasons for persistence of child marriage among the Maasai society of Kilosa district. This part of the study is divided in three sub-parts namely: the situation of child marriage among the Maasai society, techniques used by Maasai to marry Maasai girl-students and reasons for persistence of child marriage among the Maasai society.

\subsubsection{The situation of child marriage among the Maasai community}

Understanding the situation of child marriage practices among the Maasai was a very important sub-task before analysing the reasons for its persistence. The findings of this study revealed that child marriage practices still exist in the Maasai society and the Maasai community has no specific age for marriage. Most girls are married at a very young age as specified by one of the students at Magabe secondary school:

...a child is married while still young. Example, there is a child who is married in that house (pointing to the neighbouring boma-household). She was brought there since she was very young - at the age of approximately 6 . She did not even know if she was married. Currently she is like 12 years old and she wears two clothes (indicating motherhood). She lives with her husband in one house (Participant 04, interview, August 03, 2017).

This means that a girl may be married as young as 6 years with the claim that maturity is not a problem for marriage. This makes us aware of how these children 
Mkwawa Journal of Education and Development, Vol. 2, 49-71. DOI:

https://doi.org/10.37759/mjed.2018.2.1.4

Child Marriage among Maasai Girl Students in Tanzania are highly humiliated and denied of their basic rights contrary to what Human Rights Theory demands. Child marriage alienates a child couple from her parents making her lack parental care. The Tanzanian government in the Law of the Child Act No. 21 of 2009 section II (a) 7 (2) states that a person shall not deny a child the right to live with his/her parents, guardian or family and to grow up in a caring and peaceful environment unless it is decided by the court (URT, 2009). This law gives a child the right to grow up with his/her parents until s/he reaches maturity. Child marriage practices are denying this right from many children making them not to get parental care. This makes children to become irresponsible mothers later leading to underdevelopment and everlasting poverty.

Initiation ceremony is the first qualification and criteria for a Maasai girl to be married off. Where there is no specific age for a girl to be initiated, the research findings revealed that a Maasai girl is married immediately after her initiation ceremony. The findings of this study indicate further that in the Maasai culture initiation ceremony qualifies a girl to be married regardless of her age and schooling. These findings are similar to the findings of Mtewele (2012) which revealed that girls are married immediately after initiation ceremony. Mtweve (2014) also added that society members' attitude is that after initiation ceremonies girls are considered ready for motherhood and marriage. His findings revealed that due to this attitude those girls who are initiated are discouraged to go back to school. As we have noted earlier, there is no specific age for initiation ceremony among the Maasai. Where as in other Tanzanian societies (apart from Maasai) these ceremonies are done to girls at puberty age (Mtewele, 2012), to the Maasai it may be done even before puberty. According to the findings of this study, initiating a girl before puberty has become the tradition in the Maasai community. This is done by parents to avoid misfortune that may be brought by girls who become pregnant before being initiated.

Child marriage practices are present among the Maasai girl-students. Many of them are frequently absconded from school for marriage. The data from Magabe secondary school indicate high rate of girls' dropout to an average of 45.9\% (see Table 2). The findings of this study have revealed that Maasai girls who join form one rarely complete secondary education. Their major drawback is child marriage. For instance, only 4 out of 24 Maasai girls who joined form one in 2013 completed their form four in the year 2016; 20 girls did not complete their secondary education. In the year 
Mkwawa Journal of Education and Development, Vol. 2, 49-71. DOI:

https://doi.org/10.37759/mjed.2018.2.1.4

Child Marriage among Maasai Girl Students in Tanzania 2017, Magabe secondary school had only 3 Maasai girls in form four class who were expected to complete their secondary education. The number of Maasai girl-students decreases with the increase of class level while that of girl-students from non-Maasai tribes is consistent as Table 3 indicates. The major reason for the decrease in number of Maasai girl-students is marriage that makes them drop out from school.

Table 2: Magabe Secondary School girls' dropout rate by 2017

\begin{tabular}{llllll}
\hline \multicolumn{2}{l}{ Enrolled in Form I } & \multicolumn{2}{l}{ Present at School } & \multicolumn{2}{c}{ Dropout Rate } \\
\hline Year & Enrolled & Form & Present & No. & Percentage \\
2017 & 42 & I & 30 & 12 & 28.6 \\
2016 & 46 & II & 40 & 6 & 13 \\
2015 & 66 & III & 27 & 39 & 59 \\
2014 & 44 & IV & 19 & 25 & 56.8 \\
2013 & 44 & IV-2016 & 15 & 29 & 65.9 \\
TOTAL & 242 & & 131 & 111 & $45 \cdot 9=$ \\
& & & & & average \\
\hline
\end{tabular}

Source: Data from Magabe Secondary School Students' dropout forms

Table 3: Magabe Secondary School girl-students' enrolment by Ethnic groups as per August 2017

\begin{tabular}{llll}
\hline Form & Maasai & Other Tribes & Total \\
\hline FORM I & 18 & 12 & 30 \\
FORM II & 26 & 14 & 40 \\
FORM III & 15 & 12 & 27 \\
FORM IV & 03 & 16 & 19 \\
TOTAL & 62 & 54 & 116 \\
\hline
\end{tabular}

Source: Class attendance registers: August 7, 2017.

\subsubsection{Techniques used by Maasai to marry off girl-students}

Before discussing the reasons for persistence of child marriage among the Maasai, it was important to discuss the techniques employed by society members to marry off Maasai girl-students. Thus, the paper identifies the following techniques used by society members to take out girls from school for marriage.

Persuasion and Pressure

Persuasion and pressure from society members is the major technique used by society members to marry the Maasai girl students easily. The findings of this study show that society members persuade girls to prefer marriage to schooling. This is not only done to girls but also to their parents and guardians. When the girl is targeted for marriage and there is some kind of resistance, people are deliberately sent to her to persuade and soften her mind to accept marriage. This technique precedes others 
Mkwawa Journal of Education and Development, Vol. 2, 49-71. DOI:

https://doi.org/10.37759/mjed.2018.2.1.4

Child Marriage among Maasai Girl Students in Tanzania and when it fails other techniques are used. The chairman of the school board noted that:

Mothers may persuade their daughters to hate schooling and accept marriage. Male parents are intimidating their daughters that they will curse them if they don't accept marriage. Girls fear magic power and thus they have to get married (School board chairperson, interview, August 04, 2017).

According to the findings, persuasion and pressure is accompanied by strong traditional beliefs on child marriage. Strong superstitious beliefs force girls to accept marriage due to fear of parents' curse and superstitious mistreatments through witch doctors. Maasai girls at Magabe secondary school showed a strong fear in superstition to the extent of acknowledging that girls can do nothing to rebuff marriage.

\section{Transfer of students}

This is another technique employed when persuasion fails and there is no any other means that parents can use to take off girls from school for marriage. One girl specified that:

...a parent can pretend to transfer her daughter from one school to another. When a girl is permitted for the transfer to another school, parents divert her to marriage (Participant 07, interview, August 4, 2017).

The Ward Councillor further added that:

...They are using transfer technique where they transfer their daughters to other schools. When these girls reach those schools they are then easily absconded using bribery (Ward councillor, interview, August 5, 2017).

The above interview excerpts show that transfer technique is used by society members to remove girls from schools. The transfers are mostly directed to private schools where it is easy to remove students from school. It was also said that when parents take girls far away, it takes time for government leaders to discover that they are married. When a girl spends a long period in marriage it is not easy to free her from marriage since she either becomes pregnant or adapt to and accept the marriage situation.

\section{Treachery}

Related to transfer, treachery was also mentioned as a technique used by parents to make marriage of Maasai girl-students happen. Government leaders are tricked by parents that they will send their daughters to school at the beginning of the school 
Mkwawa Journal of Education and Development, Vol. 2, 49-71. DOI:

https://doi.org/10.37759/mjed.2018.2.1.4

Child Marriage among Maasai Girl Students in Tanzania year when form one students are to report to secondary schools. After these leaders stop making a follow up, girls are easily married. One girl-student at Magabe Secondary School explained that:

...many girls were married when we completed standard seven. When the government leaders made a follow up parents tricked them that they would soon send their daughters to school. When these leaders stopped the follow up these parents never sent their daughters to school. (Participant o9, interview, August 04, 2017).

From these words we learn that government leaders make a follow up in the beginning of the year to make sure that those who have been selected to join secondary education report to school. This is the time when we hear top government leaders in the media pressing against those parents who hesitate to take their children to school. After few months these voices are never heard again and parents are aware of this situation in the very beginning. Those at school are removed while those not yet reported never report to school.

\section{Pregnancy}

Pregnancy was also mentioned as a technique used to marry-off Maasai girlstudents. This is done when a girl has agreed to marry while her parents and/or teachers resist. The girl with her fiancée start sexual relationship to get pregnant. An interview with a school board chairperson was revealing of this:

...A mother may plan a trick to make her daughter who is schooling get pregnant so that she gets married. Pregnancy technique may be arranged between daughters' parents and her expected husband. A girl may also be involved in this arrangement. They know that when a girl is already pregnant, she cannot continue with schooling (School board chairperson, interview, August 5, 2017).

Parents are aware that after their daughters become pregnant they cannot be allowed to stay at school. After the girl becomes pregnant she is expelled from school though there is no any law in Tanzanian legal documents that states so (URT, 2017). As the quote above suggests, the decision to become pregnant is made in collaboration with parents, their daughter and the prospective husband.

\subsection{Reasons for persistence of child marriage among the Maasai girl students}

The research findings identified several reasons for persistence of child marriage among the Maasai girl-students and the whole community. The data collected through interview, FGDs and observation identified Maasai cultural traditions and 
Mkwawa Journal of Education and Development, Vol. 2, 49-71. DOI:

https://doi.org/10.37759/mjed.2018.2.1.4

Child Marriage among Maasai Girl Students in Tanzania norms, fear of early pregnancies, corruption and irresponsibility of leaders, poverty and undervaluing of education as the factors contributing to persistence of child marriage among the Maasai community.

\subsubsection{Maasai traditions and norms}

Maasai ethnic group is highly appreciated for keeping and maintaining their original traditions and norms. These Maasai traditions and norms hold much about child marriage. The Maasai culture allows and praises child marriage especially to girls. A ward councillor specified that:

These marriages result from traditions and norms of this society. In this society there is no consent of a married girl. Any man may marry her even if he is an old man. (Ward councillor, interview, August 05, 2017).

As we have seen previously, early marriage among the Maasai is considered important and worthwhile than the late one. This has been part of their culture and it is stimulated by other traditions. Initiation ceremonies are among the Maasai traditions which stimulate child marriage. As we have seen earlier, these ceremonies are a pass mark that qualify girls for marriage. Apart from that, during these ceremonies is when girls are exposed to men for choice of fiancées. Girl-students at Magabe secondary school had the following to say about this:

...we cannot be protected. When we go for June ceremonies that is when we meet men. When these men see young girls they start arranging for their marriage. When a girl is initiated in the last ceremony, she is considered ready for marriage. (Participant 15, interview, August 05, 2017).

These young girls meant that these ceremonies are for choice of girls to marry. It is during this time when men who wish to add a wife meet these young girls and choose the right one. These ceremonies are practised each year and are part of Maasai's cultural practice. Immediately after the ceremonies, most of young girls who are initiated get married.

Lack of mother and daughter's involvement in marriage decision is another traditional factor contributing to persistence of child marriage among the Maasai. The Maasai tradition disregards women in decision making on any matter relating to the development of the society. This study revealed that lack of women participation on marriage decisions is contributing much to child marriage. If there is no pressure from society members there is no any Maasai mother who could prefer child marriage to her daughter. All mothers who participated in this study showed a 
Mkwawa Journal of Education and Development, Vol. 2, 49-71. DOI:

https://doi.org/10.37759/mjed.2018.2.1.4

Child Marriage among Maasai Girl Students in Tanzania preference of delayed marriage to early marriage. They both claimed of not being involved in making decision on marriage of their daughters since it is not part of their customs. Less involvement of women in decision-making results from societal orientation towards the role of women, which also contributes much to child marriage. The findings of this study show that the Maasai traditions consider the role of women as limited to bearing and rising children. This societal orientation on the role of women was also reported studies by Salehe (2014) and Yotham (2010).

\subsubsection{Fear of early pregnancies}

The fear of early pregnancies among the Maasai society makes parents allow child marriage to their daughters before or at puberty. When Maasai parents were asked on the reason for preference of child marriage, they mentioned fear of pre-marital pregnancies. One of them said:

...Pre-marital pregnancies is a problem. Our traditions do not allow a Maasai girl to be initiated while pregnant because it may bring curse to the society. (Participant 30, interview, August 06, 2017).

The Maasai have strong traditional beliefs in superstition and curses. When a girl becomes pregnant before initiation and marriage, they believe that it brings curse to parents who did not take care of her by delaying her initiation and marriage. To prevent this from happening, parents make sure that they initiate girls as early as possible before reaching the age which can bring curse.

\subsubsection{Corruption and irresponsibility of leaders}

Corruption and irresponsibility of leaders was also mentioned as a reason for persistence of child marriage to girl-students among the Maasai. The data collected through interview and focus group discussion indicate that corruption and irresponsibility of leaders slow down the efforts by activists against child marriage in the area. One of participant asserted that:

Names of girls whose parents wish to marry off are cancelled in the list of those who pass standard seven to join form one. You may wonder a girl who was the leading in the class is not in the list (giving an example of her married classmate whose name appeared in the National Examination Council of Tanzania (NECTA) website and missed on the school notes board list). All this was possible through corruption (Participant 1, FGD 2, August 08, 2017). 
Mkwawa Journal of Education and Development, Vol. 2, 49-71. DOI:

https://doi.org/10.37759/mjed.2018.2.1.4

Child Marriage among Maasai Girl Students in Tanzania Local government leaders are bribed by men to assist in making marriage of Maasai girl students possible. The quote above indicates that some heads of school and other irresponsible educational officers are also bribed to remove girls from schools for marriage. Names of the targeted girls are removed from the list of those who passed the examination in the very beginning to make responsible leaders and the community believe that they failed the examinations.

\subsubsection{Poverty}

Poverty among parents was also identified as a reason for persistence of child marriage among the Maasai. The study findings show that the desire for cattle paid as bride price to the parents makes them see the importance of marrying their daughters very early. Girls are seen as a means of adding livestock to the family. It was said that a Maasai man values her daughter with 12 to 15 cattle. When a father and other relatives have already been given cattle for bride price there is no means to save their daughter from early marriage. These findings are similar to those reported in Bingham (2011) who asserted that a Maasai man is ready to sell her daughter aged 13 years to an old man of 70 years provided that the old man is rich. This research revealed that many Maasai young girls are married to men of their 'grand fathers' age due to the fact that old men are the ones who possess a large number of herds compared to young men.

Additionally, poverty reduces girls' chance to attend schools due lack of resources to finance their education expenses. Maasai girls who are not at school have a greater chance of being married at tender age. Lack of enough resources to sponsor education makes parents opt not to take girls to school. When girls stay at home parents opt for their marriage since they see them as having nothing to do.

\subsection{The position of education stakeholders in protecting a girl-child from early marriage}

The second objective of this research was to assess the position of various education stakeholders in protecting a Maasai girl child against child marriage. The aim was to understand the position and contribution of these stakeholders on girls' education attainment and success.

\subsubsection{Parents}


Mkwawa Journal of Education and Development, Vol. 2, 49-71. DOI:

https://doi.org/10.37759/mjed.2018.2.1.4

Child Marriage among Maasai Girl Students in Tanzania Parents are the first group of stakeholders which is responsible for making sure that children attend school without being debilitated by anything. The findings of this study suggest that many Maasai parents are not responsible in protecting their daughters against child marriage. They are the ones who advocate for child marriage. The headmaster of Magabe secondary school commented that:

In general, parents are to be responsible for success of children. In this area, they don't care about education. They view schooling as an obstacle to development and welfare of their children and society in general. They see education as alienating children from their society (Headmaster, interview, August 04, 2017).

The decision of parents to marry off their daughters at young age is made under pressure from the society and strong beliefs attached to child marriage. A study by Salehe (2014) found that socialisation of parents makes them convince each other to marry off and not to educate their daughters. However, there are some parents, especially female parents, who do not support child marriage. The findings show that many female parents do not want their daughters to get into marriage before maturity. Unfortunately, they are not involved in decision making and therefore they have nothing to do to prevent their daughters from early marriage due to a strong patriarchal system existing in the Maasai community. Apart from that, they are highly intimidated by their husbands not to go against their decisions. Their voices are always muted by these husbands who regard them as having nothing to contribute in development of the society.

\subsubsection{Teachers and school administrators}

The findings suggest that primary school teachers are more helpful than secondary school teachers in controlling students' marriage. About $85 \%$ of research participants acknowledged primary school teachers on their efforts to save standard seven leavers from marriage. These teachers are helping students who have just entered in the hands of secondary school teachers and administrators. Indeed, these are additional efforts to be acknowledged. Society members who wish to marry these girls are aware of the strengths of primary school teachers as well as the weaknesses of secondary school teachers, thus finding a loophole to fulfil their mission. When it happens that they face difficulties to marry a girl after she has just completed standard seven, they wait when she is about to join secondary school where she can be easily taken. 
Mkwawa Journal of Education and Development, Vol. 2, 49-71. DOI:

https://doi.org/10.37759/mjed.2018.2.1.4

Child Marriage among Maasai Girl Students in Tanzania Poor cooperation between secondary school administrators and teachers as well as negligence among them is the major reason for their poor performance in controlling students' marriage. A teacher at Magabe secondary school commented that:

.... I used to hear such cases from the headmaster where they end up with a girl being taken for marriage. We never sat as staff to discuss cases on child marriage. At this school things are done secretly. No any strategy taken by the school administration (Teacher 2, interview, August 03, 2017).

This comment indicates that there is little effort taken by teachers and the school administration in protecting Maasai girl students against child marriage. The findings of this study show that secondary school teachers and school administrators witness many girl students' marriage cases but they do little to prevent girl students from early marriage. In reviewing staff meeting minutes, the researcher never saw any agenda on child marriage.

However, these secondary school teachers were acknowledged on controlling students discipline and academic performance thus helping girls pass their examinations to stay in schools. The control of students' behaviour is important to make girls enjoy studying thus not easily accepting marriage. It also improves students' academic performance to make parents not to find reasons of absconding them from schools for marriage.

\subsubsection{Government leaders}

Government leaders have a responsibility of making sure that all children attend school according to the laws of the country. This study assessed the position of government leaders at the local government level because these are the key implementers of the laws of the country. The research findings suggest that few of these leaders are acting responsibly in controlling child marriage. Many of them are corrupt and affected by Maasai traditions that perpetuate child marriage since they are the products of the Maasai society. One participant commented that:

I can say that in these areas there are no efforts done by government leaders.

This is because of the traditions. Since leaders are part of the society, they do not see child marriage as a problem. Even daughters of leaders are married young (Participant 11, interview, August 04, 2017).

Since local leaders are the product of the Maasai society they collaborate with society members to encourage child marriage. A ward councillor, when interviewed on the mentioned examples of child marriage cases, he accepted since many Maasai girl 
Mkwawa Journal of Education and Development, Vol. 2, 49-71. DOI:

https://doi.org/10.37759/mjed.2018.2.1.4

Child Marriage among Maasai Girl Students in Tanzania students were in marriage. No any Maasai girl student who was reported to have been completely prevented from marriage by these leaders. They never reported child marriage cases to the top government leaders as the ward councillor said:

...we cannot blame top government leaders because it is this year [2017] when we have for the first time reported these cases to the court. It is now when we are planning to report these cases to the District Commissioner and District Executive Director (Ward councillor, interview, August 04, 2017).

If local leaders are not reporting child marriage cases to top leaders, there is no way we can blame top government leaders.

\subsection{Strategies to reduce child marriage among the Maasai society}

The third and last research objective was to identify strategies to be taken to reduce child marriage among the Maasai. Several strategies were identified by participants as follows:

\subsubsection{Enacting laws and ensuring their proper implementation}

The government was pointed by participants as the first actor in designing measures to combat child marriage. A ward educational officer suggested that:

...a powerful government should be the first actor in controlling this. When it decides to do anything, it can never fail. It is the government that should empower us for our actions to be effective... (Participant 11, interview, August 04, 2017).

The participants of this study believe that the government is more powerful to control child marriage. This is possible where it is free from corruption and it has established strong laws prohibiting child marriage. Top government leaders should not assume that local leaders are acting effectively. Low-level leaders should put aside their personal and societal biases for them to successfully end child marriage practices.

\subsubsection{Improving enrolment and retention}

Strategies to improve enrolment and retention of all children in schools should be given priority by child marriage activists and educational planners. Girls in schools get chance of extending their age before marriage. As we have seen earlier, Maasai girls not in schools are easily married off at their young age. Measures to improve their schooling such as establishing schools in the remote areas and improving learning environment should be taken. School learning environment for girls should 
Mkwawa Journal of Education and Development, Vol. 2, 49-71. DOI:

https://doi.org/10.37759/mjed.2018.2.1.4

Child Marriage among Maasai Girl Students in Tanzania be improved to make girls enjoy schooling and prefer to stay in schools rather than marriage.

\subsubsection{Education to the society}

Education to society members and girl-students is another strategy identified by this study. Various stakeholders should put more efforts to educate the Maasai community on the impact of child marriage and the importance of girl's education.

One participant suggested that:

...the government should provide education to parents and help girls from poor families to get access to education. Girls should also be educated to escape from marriage (Participant 16, interview, August 05, 2017).

The quote above means that if parents and all society members become aware of the importance of girls' education to the society as well as the negative impact of child marriage, it can be possible to eliminate child marriage. URT (2017) and Yotham (2010) recommended that parents and community members should be educated on the importance of girls' education. Girls also need to be educated on the way they can escape from marriage and the importance of education in their life. The findings show that if a girl child hates marriage and resists it, there is no way she can be married. Girl-students at Magabe secondary school told a story of a girl student from Village $\mathrm{C}$ who succeeded to escape marriage by running naked to the police post at Kimamba:

...she was forced into marriage by her father after completing standard seven. She told her father that she won't be married by any means. When her father arranged for her marriage ceremony, she woke up very early in the morning of the day of her marriage ceremony to go to the police station. On the way she met an old man who was aware of her ceremony, thus knowing that she is escaping. She decided to undress and remain naked so she could be able to pass over that old man without any conversation. She succeeded reporting to the police where they cancelled that wedding (Participant 1, FGD 1, August 3, 2017).

These girls showed that they need to be empowered by education to enable them resist child marriage. If all girls become courageous like that girl, there will be no problem of child marriage. At the level of secondary education a girl is at least 
Mkwawa Journal of Education and Development, Vol. 2, 49-71. DOI:

https://doi.org/10.37759/mjed.2018.2.1.4

Child Marriage among Maasai Girl Students in Tanzania mature to recognise sexual humiliations like child marriage. Her awareness needs to be enhanced by sexual and reproductive health education (URT, 2017).

\subsection{Conclusions and recommendations}

\subsection{Conclusions}

Based on the findings presented above the following conclusions can be drawn: first, ignorance and strong cultural practices of the society members contribute much to child marriage among Maasai girl-students. Second, child marriage is considered legitimate by society members. Third, joint efforts are needed in combating child marriage among girl-students in Tanzania. Fourth, the government needs to use its authority to enrich the efforts of other actors. Finally, unless society members and girls are well educated on the effects of child marriage, the problem of child marriage cannot be adequately addressed.

\subsection{Recommendations}

Indeed, girls' dropout rate for marriage is very high among the Maasai community. Immediate actions to free the recently married girls are needed. The ministry of education should make sure that all girls who are selected to join secondary education attend school and complete their secondary education. Close monitoring strategies should be developed in areas like students' attendance and transfer of girls to other schools. In addition, school learning environment for girls should be improved in schools to make girls prefer schooling to any other advice from community members. Guidance and counselling programs should be established in schools, starting with those schools in societies with high prevalence of child marriage. Regular and continuous patrols should be made through local police officers to make sure that child marriage cases are controlled. Punishment to those marrying girl students should be specified and implemented to society members.

When transfer of students is made, a close follow up to the destination school should be made to make sure that the transferred students attend at their new school. Also, school administrators should report girl students' marriage cases immediately after discovering them and make sure that those girls return to school. They should not just report and keep silent since leaders may not be responsible. The findings of this study indicated that child marriage is supported by traditions and customs. Therefore, it is recommended that more education on negative impact of child marriage should be provided to societies with strong cultural ties like the Maasai. 
Mkwawa Journal of Education and Development, Vol. 2, 49-71. DOI:

https://doi.org/10.37759/mjed.2018.2.1.4

Child Marriage among Maasai Girl Students in Tanzania The findings of this study indicate that education on the impact of child marriage is needed to change the attitude of society members. It is thus recommended that this education should be included in the curriculum at all levels of education. In-service training to teachers and heads of school on ways of combating child marriage should be planned and implemented regularly to enhance teachers' ability to prevent child marriage. The ongoing process of amending the law of marriage Act of 1971 should make sure that the minimum age for marriage of the girl child is above 18 years. This is because at the current age of 15 years for girls and 18 years for boys, the child is still attending secondary education which according to the Education and Training Policy of 2014 is compulsory to all children.

This study was based on the Maasai community of Kilosa district in Morogoro region. This is indeed a very small area. It is therefore recommended to do similar studies in other areas of Tanzania to widen the scope for understanding the girl child marriage in Tanzania. A comprehensive quantitative study to determine the actual number of girl children, including girl-students, who are married each year in the study area is recommended. This will help to assess the magnitude of the problem. Though this study was limited to girl-students alone, it found out that there are many Maasai girls not at school who are direct victims of child marriage. We therefore, recommend a study on persistence of child marriage among Maasai community to include direct victims of the practice. Also the researcher recommends a comparative study in other pastoral societies in Tanzania to see if reasons for persistence of girlstudents marriage among the Maasai are similar to other pastoral societies.

\section{References}

Ary, D., Jacobs, C. L., \& Sorensen, C. (2010). Introduction to research in education (8th ed.). New York: Wadsworth Cengage Learning.

Bachar, M. (2012). The Maasai's perception of female education and Maasai girls' perception of their educational experiences in Kajiado, Kenya (Master's thesis, Universiteit Van Amsterdam).

Backlund, H., \& Blomqvist, G. (2014). Protecting the girl child or upholding patriarchy?: A case study of child marriage in the cultural and legal context of Tanzania. Lund University: SIDA.

Bali, T. A., \& Mbavai, S. (2015). Exploring perceptions of agro-pastoralists on girls' education among the Maasai, Wa-Meru and Wa-Arusha of Tanzania. The Journal of Humanities, 2, pp. 56-61.

Beiter, K. D. (2006). The protection of the right to education by international law, Vol. 82. Leiden/Boston: Martinus Nijhoff Publishers. 
Mkwawa Journal of Education and Development, Vol. 2, 49-71. DOI:

https://doi.org/10.37759/mjed.2018.2.1.4

Child Marriage among Maasai Girl Students in Tanzania

Bingham, K. S. (2011). Helplessness to hope: cultural transformations for the maasai girl-child (Unpublished doctoral dissertation). Liberty University, Lynchburg, VA.

Carr-Hill, R., \& Peart, E. (2005). The education of nomadic peoples in East Africa: Djibouti, Eritrea, Ethiopia, Kenya, Tanzaia and Uganda; Review of relevant literature. Angle and Paris: ADB/UNESCO-IIEP.

Harvey, R., \& Myers, J. (2011). Breaking vows: Early and forced marriage and girls' education. Retrieved October 10, 2016 from http://www.planuk.org/resources/documents/breaking-vows-early-and-forced-marriage-andgirls-education/

Donnelly, J. (2013). Universal human rights: In theory and practice ( $3^{\text {rd }}$ ed.). Ithaca and London: Cornell University Press.

Kombo, D. K., \& Tromp, D. L. (2006). Proposal and thesis writing: An introduction. Nairobi: Paulines Publications Africa.

Michael, R. (2014). Factors which contribute to early marriage among teenagers in rural areas: A case study Kasulu district in Kigoma region (Unpublished master's dissertation). The Open University of Tanzania, Dar es Salaam.

Mlekwa, V. M. (1996). State, pastoralists and education in Tanzania: How can conflicts and tensions be resolved? UTAFITI (New Series), 3(1), pp. 47-65.

Mtengeti, S. K., Jackson, E., Masabo, J., William, A., \& Mghamba, G. (2008). Report on child marriage survey conducted in Dar es Salaam, Coastal, Mwanza and Mara regions: December 2007-May 2008. Dar es Salaam: Children's Dignity Forum.

Mtewele, G. C. (2012). The influence of traditional customes and practices on girls' secondary education in Morogoro region in Tanzania (Unpublished master's thesis). University of Oslo, Institute of Educational Research.

Mtweve, S. (2014). Assessment of effect of Wapangwa culture on girls' education in Ludewa district: The case of mount Masusa and Chief Kidulile secondary school girls (Unpublished masters dissertation). University of Dar es Salaam, Dar es Salaam.

Nguyen, C. M., \& Wodon, Q. (2012). Global trend in child marriage. New York: World Bank.

Osborn, D., Cutter, A., \& Ullah, F. (2015). Universal Sustainable Development Goals: Understanding the transformational challenge for developed countries, Report of a study by stakeholder forum. Retrieved on December 2, 2016 from https://sustainabledevelopment.un.org/content/documents/1684SF - SDG

Raymond, A. (2012). Girls' education in pastoral communities: An ethnographic study of Monduli district, Tanzania. Retrieved February 27, 2017 from http://www.educationdevelopmenttrust.com

Salehe, H. (2014). Attitude towards girls' secondary school education in community secondary schools: A case of Igunga district, Tanzania (Unpublished masters dissertation). University of Dar es Salaam. Dar es Salaam. 
Mkwawa Journal of Education and Development, Vol. 2, 49-71. DOI:

https://doi.org/10.37759/mjed.2018.2.1.4

Child Marriage among Maasai Girl Students in Tanzania

Temba, I. E., Warioba, L., \& Msabila, D. T. (2013). Assessing efforts to address cultural constraints to girls' access to education among the Maasai in Tanzania: A case study of Monduli district. Journal of International Cooperation in Education, 15 (3), pp. 21-37.

UNESCO. (2014). Road map for implementing the global action programme on education for sustainable development. Paris: United Nations Educational, Scientific and Cultural Organization.

UNESCO. (2015). Sustainable development begins with education: How education can contribute to the proposed post-2015 goals. Retrieved on $20^{\text {th }}$ October 2016 from http://unesdoc.unesco.org/images/0023/002305/230508e.pdf

UNICEF. (2001). Early Marriage: Child Spouses. Italy: Innocenti Research Centre.

UNICEF. (2007). A human right-based approach to Education for All: A framework for realization of children's right to education and rights within education. New York: UNICEF/UNESCO.

UNICEF. (2013). Ending Child Marriage:Progress and prospects. Retrieved on $\begin{array}{llll}\text { November } & 6, & 2016 & \text { from }\end{array}$ https://www.unicef.org/media/.../Child Marriage Report 7 17 LR..pdf

UNICEF. (2015). Child marriage, adolescent pregnancy and family formation in West and Central Africa: Patterns, trends and drivers of change. Retrieved November $2, \quad 2016 \quad$ from www.icrw.org/.../Child Mariage Adolescent Pregnancy and Family F..

URT. (1995). Education and Training Policy. Dar es Salaam: The Ministry of Education and Culture.

URT. (2009). Act Suppliment No.21: The Law of the Child Act, 2009. The Gazette of the United Republic of Tanzania, 90(52), pp. 655-726.

URT. (2014). The Tanzania Education and Training Policy, 2014. Dar es Salaam: Tanzania Ministry of Education and Vocational Training.

URT. (2017). National survey on the drivers and consequences of child marriage in Tanzania. Dar es Salaam: Ministry of Health, Community Development, Gender, Elderly and Children.

WHO. (2013). Child marriages: 39 ooo every day. Retrieved November 7, 2016, from

http://www.who.int/mediacentre/news/releases/2013/child marriage 20130307 Len/

Williams, J. (2015). A Brief History of International Education Policy: From BretonWoods to the Paris Declaration. In C. A. Brown (Ed.), Globalization, international education policy and local policy formation: Voices from the developing world. New York \& London: Springer.

Yotham, T. (2010). The effects of parental and community attitudes on girls' education and academic progress in Kuria community in Tarime district (Unpublished masters dissertation). University of Dar es Salaam, Dar es Salaam. 